\title{
REVIEW
}

\section{Deep Time Horizons: Vincent lalenti's Deep Time Reckoning: How Future Thinking Can Help Earth Now. Cambridge, MA: MIT Press}

\author{
Rony Emmenegger
}

Deep Time Reckoning highlights that humanity must find new ways to inspire and structure temporal thinking when dealing with the contemporary crisis of the 'Anthropocene'.

Keywords: Deep Time; nuclear waste; geo-history; long-termism; natural analogues; scientists

I gaze into the distance from the castle mount in Burgdorf, Switzerland, on a foggy morning just before sunrise. I am here with my family. We took up a habit of interrupting the academic semester in late November, to slow down before its terminal phase - a slow-down that appeared to be inevitably about to happen in face of the unfolding Corona pandemic. This year, we had selected the youth hostel in Burgdorf as the site for this short vacation, because it is spectacularly situated in an old castle at the top of a sandstone hill (Figure 1). Sitting at the breakfast table within the castle walls, the glass façade allows you to overlook the hilly landscape towards the South, the ridges emerging from the twilight with decreasing colour intensity at distance.

In that end of November day, the horizontally layered landscape had opened a window into deep time. The scenery had caught my attention as it so obviously mirrored the aquarelle book cover of Vincent Ialenti's Deep Time Reckoning, which I had brought with me and which inspired my reflection. Deep Time Reckoning highlights that humanity must find new ways to inspire and structure temporal thinking when dealing with the contemporary crisis of the 'Anthropocene'. Being formulated as a critique of short-termism and the failure to consider humanity's long-term impacts, the book offers a practical guide for 'future thinking' that 'can help Earth now'. As the author highlights, 'thinking in geological timescales is now a pressing ethical imperative' (2) for humans as 'agents of geological change' (2), urging us to engage responsibly to a multi-layered 'crisis'. For Ialenti, this link between the ability to project deep time, and to engage with it responsibly is implicit in the double meaning of the term 'reckoning' - simultaneously understood as reckoning 'deep time by calculating, estimating, and drawing

Sustainability Research Group, University of Basel, $\mathrm{CH}$ rony.emmenegger@unibas.ch conclusions about the future' and as reckoning 'with the Anthropocene planetary crisis' (18). It echoes Macfarlane's (2019: 15, cited 88) recent emphasis that thinking in and about deep time should neither result in apathy nor the escape from a troubled present but rather is a way for its re-imagination - or, as Donna Haraway (2016) highlights to 'stay with the trouble' instead of trying to escape it. The book thus fits extremely well into the One Planet book series that has been created by Jinnah and Nicholson 'to showcase insightful, hope-fuelled accounts of the planetary condition and the social and political features upon which that condition now depends' (vii).

Deep time reckoning is inspired by an analysis of nuclear waste disposal in Finland. While the scientific community has for long debated about the suitability of radioactive elements from nuclear bomb testing as the Anthropocene's 'golden spike' in sediments, the issue of nuclear waste disposal - or the way it will be "written" into the Earth's history' (Brunnengräber and Görg 2017: 96) - has for long been ignored. Ialenti has now started to fill this gap. Based on an in-depth ethnographic account of Finnish safety case experts at work, Deep Time Reckoning suggests that humanity can learn from them as they have for long been concerned with the future. The book provides insights into the ways (methods, techniques, rationalities, practices, and tactics) through which these highly-trained, forward-looking scientists project plausible futures and build a 'safety case' - a bundle of questions, reasoning, and evidence for establishing 'safety' of a nuclear waste repository in the deep geological underground for the next million years (see also Röhlig and Eckhardt 2017: 103). The book proceeds in four chapters: Chapter 1 illustrates how safety case experts make use of natural analogues as entry points to think and know about distant pasts or futures. Chapter 2 demonstrates how expert modellers of safety cases make use of logical patterns (input-output, cause-effect, either/or, if/then) as heuristics to navigate within the complexity of an emerging safety case. Chapter 


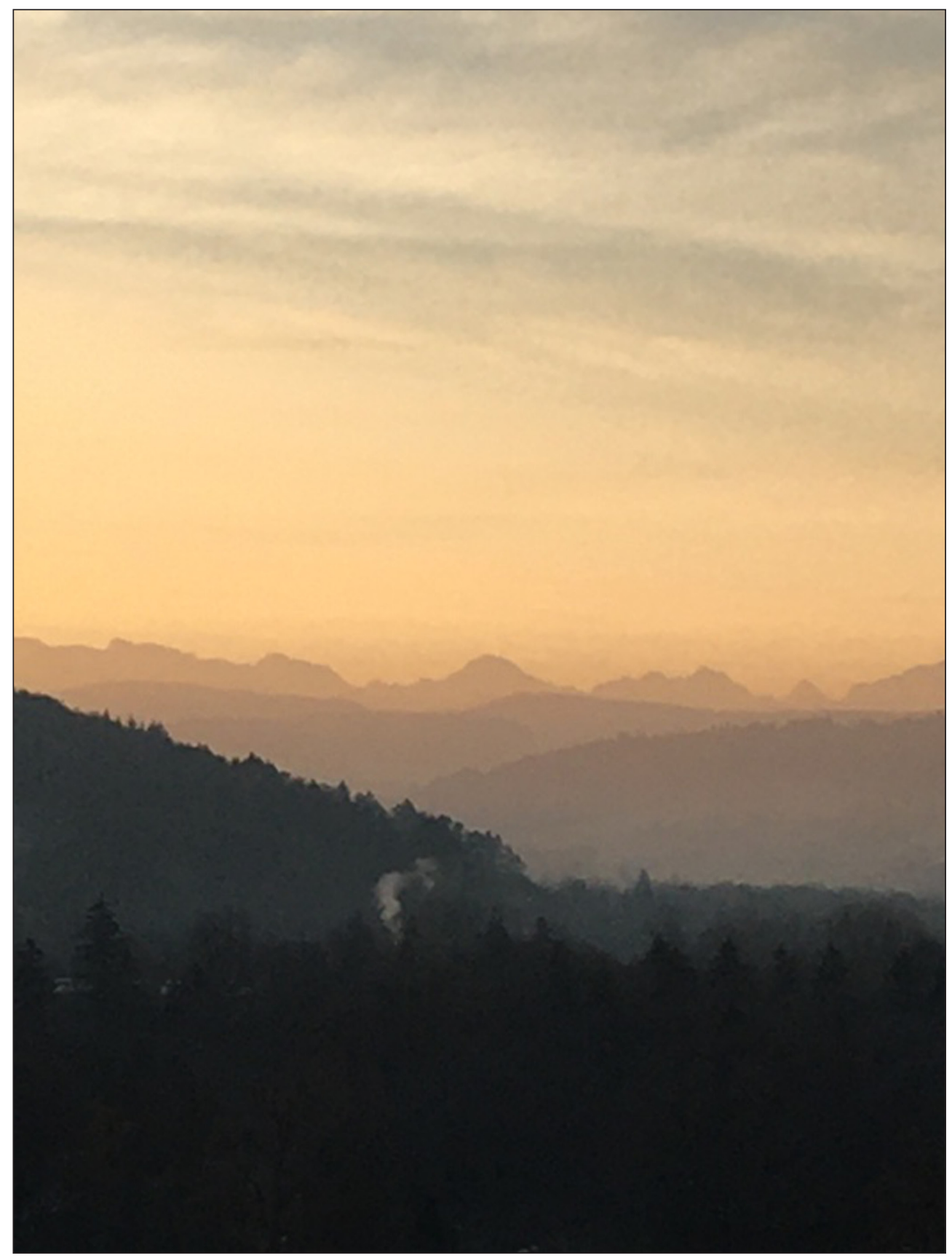

Figure 1: Burgdorf, castle mount.

3 is about zooming in, into safety case experts' workplace as sites for the projection of multiple futures, and about zooming out, into human, ecological and geological histories in which their work is embedded. Chapter 4 discusses the case of a deceased safety case expert and his afterlife, revealing the problem of expert mortality and the inherent fragility of knowledge this implies (see also Ialenti 2020). Each of these chapters culminates in an outline of a "practical toolkit for educating publics, experts and lay alike' (8) for reckoning (with) deep time: the first two offer tools for 'amateur analogizers' (59) and amateur modellers that can inspire thought experiments, structure thinking, multiply lines of reasoning, and encourage reflexivity. The second two offer strategies for building long-sighted organisations and institutions for the Anthropocene through the advance of multiscale, multi-angle, or multi-perspective sensibilities and the establishment of an ethic of 'predecessor preservation' (43) and 'succession stewardship' (141).

Deep Time Reckoning powerfully illustrates what society at large can learn from safety case experts as future-gazing guides' (8), in order to become more long-sighted in its thinking and action. Ialenti's call for the empowerment of these experts rests on the insight that societies in the Anthropocene do not only face an ecological crisis, but also a crisis of expertise. He problematizes what he calls 'the deflation of expertise' (6), manifesting in a rising global distrust between science and society - even at a time when the scientific has become "more sophisticated than ever before' (7). It speaks to his own experience as an anthropologist returning from fieldwork in Finland to the US: from a socio-political context in which a strong trust in 
science, technology, and bureaucracy enables legitimate technocratic rule; to another, in which 'alternative facts' and 'fake news' strongly work contra science-inspired decision-making. Against this backdrop, Deep Time Reckoning entails a strong political claim to push back and bring 'expertise closer to the centre of societal decision making' (9). To be precise, lalenti is not calling for a shift to technocratic rule in which lay publics simply have to 'trust', but to overcome the widespread distrust between experts and lay people. Deep Time Reckoning reads as a call to open political space for citizens and lay people to become engaged with multi-temporal futures. While it encourages creativity and flexibility in thinking, the book also suggests to regularly calibrate such vernacular future thinking based on scientific evidence and findings in order to achieve 'greater accuracy' (87). In turn, it highlights that humanity has a duty, as 'science and technology can never teach us what to value, how to pursue a good life, how to act morally, or how to navigate delicate situations' (37).

Deep Time Reckoning constructively builds on a tension between the necessity to rely on expertise and the significance of reflecting scientific facts, knowledge, and authority. It reveals model-based scenarios about the future to be only as good as the data available to the expert, and as good as the expert's attitude to reflect and use it. It draws attention to the institutionally embedded and embodied nature of scientific knowledge, demythologising safety case experts as 'specialists' and demonstrating how their personal preferences, creativity, and relations potentially impact on their scientific choices and proceedings. Furthermore, it reveals safety case experts as operating within contemporary geoscientific paradigms, such as uniformitarianism - or the principal idea in geology that 'the present is the key to the past'. Uniformitarianism rests on an understanding of the Earth's changeas an incremental process according to natural laws that do not change over time - and thus stands in contrast to 'catastrophism' that used to inspire geoscience until the eighteenth century (see also Ghosh 2016: 33; Bjornerud 2018: 24). Ialenti uses analogy as a quintessential example of uniformitarian method, through which past phenomena are explored 'by making analogies with phenomena observable today' (53). I read his discussion of the work of modellers as a further example of the paradigmatic nature of geoscientific knowledge: ever more sophisticated models of the Earth and its model-based futures do not only reflect an ever more detailed understanding of complex Earth system dynamics, but equally mirror a belief that controlling or transforming the Earth system is possible if only we understand it to be analogous to clockwork. Indeed, unsettling scientific 'truth' und unveiling the constructed nature of scientific knowledge has been instrumental for moving beyond modernist ideas of controlling nature that have for (too) long characterised governance. Deep Time Reckoning provides a valuable contribution to that end, unravelling the inherent fragility of any knowledge about the future and contributing to a critical scholarship in the 'Anthropocene'. Furthermore, it illustrates how such a critical scholarship can be constructively used for building new ways of thinking about the Earth's past and future and to be in a better position of decision making and 'helping Earth now'.

Deep Time Reckoning culminates in an outline of a future society that has successfully overcome short-termism and cultivated long-term thinking. Required to that end is nothing less, as Ialenti suggests, than a 'thought revolution' (144) - for which his book provides a practical guide. It suggests education, training, and capacitybuilding among citizens and authorities, in institutions and organizations, and the institutionalisation of longterm and multi-temporal thinking. It is this thinking that 'today's short-sighted organisations, especially those with long-term impacts' (111) have to adopt - either voluntarily in their 'corporate self-interest' (113) or enforced by the law of 'Anthropocene citizens' (141). And yet, I feel urged to emphasise that the transition towards such a society sensitive to its embeddedness in 'geo-history' (Chakrabarty 2009) will not be as straightforward as the reader of Deep Time Reckoning might conclude. What if projections of the future diverge fundamentally? What projection of the future should then be prioritised over others for decisionmaking? On what normative basis should such diverging projections then be evaluated; and whose voice should be heard in light of potential trade-offs between multiple, partly widely diverging goals? As these questions indicate, a transformation towards a sustainable future of humanity on Earth needs to be understood and analysed in political terms. It requires to account for the inherently political nature of knowledge about the Earth, opening up political space not only for the negotiation of diverging futures, but for what Castree et al. (2014: 766) called 'value-means-ends packages.' In this vein, Deep Time Reckoning will be most effective when being read in combination with literature on the politics of transformation, or on the politics of knowledge, uncertainty and the values this entails (see for example Eckersley 2017; Emmenegger \& Rowan et al. 2017; Hulme 2010; Lövbrand et al. 2020; Patterson et al. 2017; Voß \& Bornemann 2011). Being sensitive to the political negotiations between various deep time reckoners that is required for decision-making in the Anthropocene, is thereby essential for not falling back into authoritarian or technocratic rule - a looming threat, in the light of an increasingly powerful crisis discourse that tends to characterise current Anthropocene thinking and writing.

\section{Competing Interests}

The author has no competing interests to declare.

\section{References}

Bjornerud, M. (2018). Timefulness: How Thinking Like a Geologist Can Help the World. Princeton, NJ: Princeton University Press. DOI: https://doi.org/10.2307/j. ctvc772cs

Brunnengräber, A., \& Görg, C. (2017). Nuclear Waste in the Anthropocene: Uncertainties and Unforeseeable Timescales in the Disposal of Nuclear Waste. Gaia, 2, 96-99. DOI: https://doi.org/10.14512/gaia.26.2.8

Castree, N., et al. (2014). Changing the Intellectual Climate. Nature Climate Change, 4, 763-768. DOI: https://doi.org/10.1038/nclimate2339 
Eckersley, R. (2017). Geopolitan Democracy in the Anthropocene. Political Studies, 65(4), 983-999. DOI: https://doi.org/10.1177/0032321717695293

Emmenegger, R., Rowan, R., et al. (2017). Ontology and Integrative Research on Global Environmental Change: Towards a Critical GEC Science. Current Opinion in Environmental Sustainability, 29, 131-137. DOI: https://doi.org/10.1016/j.cosust.2018.02.001

Ghosh, A. (2016). The Great Derangement. Gurgaon: Penguin Books India. DOI: https://doi.org/10.7208/ chicago/9780226323176.001.0001

Haraway, D. J. (2016). Staying with the Trouble: Making Kin in the Chthulucene. Durham, NC: Duke University Press. DOI: https://doi.org/10.2307/j.ctv11cw25q

Hulme, M. (2010). Problems with Making and Governing Global Kinds of Knowledge. Global Environmental Change, 20, 558-564. DOI: https://doi.org/10.1016/j. gloenvcha.2010.07.005

Ialenti, V. (2020). Spectres of Seppo: The Afterlives of Finland's Nuclear Waste Experts. Journal of the Royal
Anthropological Institute, 26(2), 1-18. DOI: https:// doi.org/10.1111/1467-9655.13247

Lövbrand, E., Mobjörk, M., \& Söder, R. (2020). The Anthropocene and the Geo-political Imagination: Re-writing Earth as Political Space. Earth System Governance, 4(100051), 1-8. DOI: https://doi. org/10.1016/j.esg.2020.100051

Macfarlane, R. (2019). Underland. New York: W. W. Norton.

Patterson, J., et al. (2017). Exploring the Governance and Politics of Transformations towards Sustainability. Environmental Innovation and Social Transition, 24, 1-16. DOI: https://doi.org/10.1016/j.eist.2016.09.001

Röhlig, K.-J., \& Eckhardt, A. (2017). Primat der Sicherheit: Ja, aber welche Sicherheit ist gemeint? Gaia, 2, 103105. DOI: https://doi.org/10.14512/gaia.26.2.10

Voß, J.-P., \& Bornemann, B. (2011). The Politics of Reflexive Governance: Challenges for Designing Adaptive Management and Transition Management. Ecology and Society, 16(2), 9. DOI: https://doi. org/10.5751/ES-04051-160209

How to cite this article: Emmenegger, R. (2021). Deep Time Horizons: Vincent lalenti's Deep Time Reckoning: How Future Thinking Can Help Earth Now. Cambridge, MA: MIT Press. Anthropocenes - Human, Inhuman, Posthuman, 2(1): 7. DOI: https://doi. org/10.16997/ahip.1015

Submitted: 27 February $2021 \quad$ Accepted: 27 February $2021 \quad$ Published: 23 July 2021

Copyright: ( $) 2021$ The Author(s). This is an open-access article distributed under the terms of the Creative Commons Attribution 4.0 International License (CC-BY 4.0), which permits unrestricted use, distribution, and reproduction in any medium, provided the original author and source are credited. See http://creativecommons.org/licenses/by/4.0/.

W Anthropocenes - Human, Inhuman, Posthuman is a peer-reviewed open access journal published by University of Westminster Press. 